MichałWitek

ORCID: 0000-0001-7043-1744

Uniwersytet Wrocławski

\title{
Zbyt radykalny, by powstać? Historia Kalejdoskopu - ostatniego, nieukończonego filmu Alfreda Hitchcocka
}

Abstrakt: Między 1964 a 1967 rokiem, u schyłku swojej wielkiej kariery, Alfred Hitchcock przeżył niezwykły moment twórczego renesansu. Inspirując się dynamizmem i innowacyjnością europejskiego kina, postanowił sięgnąć po tematykę i środki, które wyprzedzały jego czasy. Niestety, jedno z potencjalnych arcydzieł współczesnego kina zostało okrzyknięte zbyt radykalnym, szokującym, a nawet odrażającym, by powstać. Niniejszy artykuł jest próbą rekonstrukcji zawiłych losów $\mathrm{Ka}$ lejdoskopu, ostatniego z nieukończonych projektów filmowych Alfreda Hitchcocka. Istniejący materiał oraz dostępne źródła zostały poddane analizie i systematyzacji w poszukiwaniu odpowiedzi na szereg pytań badawczych — między innymi na najważniejsze z nich: dlaczego projekt tak skrupulatnie przygotowywany i pod wieloma względami wizjonerski nie został ukończony? Ponadto, w ramach możliwych do ustalenia faktów, zostały podjęte próby rekonstrukcji zamysłu reżysera co do ostatecznego kształtu filmu, jego głównych motywów stylistycznych i fabularnych. Analizie poddane zostały również potencjalne związki tego projektu z wcześniejszymi i późniejszymi dziełami reżysera, a szczególnie z poprzedzającą go Psychoza (Psycho, 1960) oraz późniejszym Szałem (Frenzy, 1972).

Słowa-klucze: Alfred Hitchcock, nieukończone dzieło, Kalejdoskop, Szał

[...] Te zdjęcia, zrealizowane bez dźwięku i z udziałem nieznanych aktorów, dają niezwykłą szansę wglądu w to, co mogłoby się zdarzyć. Z pewnością jest to niesamowity materiał, który zmieniłby naszą percepcję ostatniej dekady twórczości Hitchcocka. Jego wpływ na kino byłby ogromny. Hitchcock powróciłby w tym późnym momencie swojej kariery w awangardzie stylu ${ }^{1}$.

Dan Auiler (Hitchcock's Secret Notebooks)

1 D. Auiler, Hitchcock's Secret Notebooks, New York 2001, s. 431.

Prace Kulturoznawcze 22, 2018, nr 3

(C) for this edition by $\mathrm{CNS}$ 
Reżyserów można podzielić na dwie grupy: na tych, dla których kino jest przede wszystkim spektaklem robionym dla widzów, oraz tych, którzy w ogóle nie interesują się reakcjami i gustami publiczności. Alfreda Hitchcocka można niewątpliwie zaliczyć do grupy autorów tworzących dla widzów i podchodzących do każdego nowego projektu filmowego z bardzo sprecyzowanym wyobrażeniem o docelowej widowni, dla której owo dzieło powstaje. W ciągu całej swojej kariery Hitchcock starał się przewidywać gusta i zainteresowania publiczności, co czynił $\mathrm{z}$ reguły z zaskakującą precyzją. Ten niezawodny instynkt uwidaczniał się w umiejętności dostrzegania tych tematów i motywów, które szczególnie mocno rezonują z widzem poprzez szok i strach - elementy związane dla Hitchcocka z ciekawością i zadziwieniem. Jego geniusz objawiał się w umiejętności ustanowienia balansu pomiędzy szokowaniem widza i pobudzaniem jego ciekawości poprzez budowanie suspensu, w prowadzeniu narracji generujących niezwykłe zagadki i w tworzeniu konstruktów psychologicznych, które w najmniej oczekiwanym momencie ujawniały szokujące, przerażające wydarzenia. Za kwintesencję tego rodzaju kina uznać należy Psychozę (Psycho, 1960), prawdopodobnie najbardziej znane dzieło Hitchcocka i jeden z najsłynniejszych horrorów w historii kina, który wywarł duży wpływ na odmianę psychologiczną tego gatunku w kolejnych dekadach XX wieku. Produkcję tę można uznać za jeden z najważniejszych przykładów wyzwalania się głównego nurtu kina amerykańskiego z więzów kodeksu Haysa. Był to film łamiący tabu związane $\mathrm{z}$ ukazywaniem zbrodni oraz łączący dwa motywy, które dotychczas zawzięcie zwalczano w imię obrony publicznej moralności - przemoc i seksualność. Hitchcock był zafascynowany mrocznymi obszarami, w których dochodzi do zetknięcia się tych dwóch elementów. Niewątpliwie silne były tu inspiracje klasyczną psychoanalizą — Slavoj Žižek wskazuje nawet na fakt, że mieszkanie Normana Batesa ma trzy piętra odpowiadające trzem poziomom ludzkiej psychiki w teorii Zygmunta Freuda ${ }^{2}$. Psychoza stanowi w twórczości Hitchcoka ważny moment, w którym reżyser zwraca się ku obszarom i motywom dotychczas traktowanym jako zbyt szokujące i przerażające dla głównego nurtu kina. Sukces Psychozy prawdopodobnie utwierdził go w przekonaniu, że tematyka przemocy, psychopatii oraz mrocznych aspektów seksualności może zostać skutecznie przełożona na język kina, które w dodatku odnosi sukcesy komercyjne i rezonuje $\mathrm{z}$ widownią. Tym bardziej interesujący wydaje się fakt, że Hitchcock nie zdołał powtórzyć tego sukcesu. Kolejne produkcje - Marnie (Marnie, 1964) oraz Rozdarta Kurtyna (Torn Curtain, 1966) — zostały chłodno przyjęte zarówno przez widzów, jak i krytyków, a reżyser zaczął szukać nowej stylistyki.

W niniejszym artykule skupię się na ostatnim z nieukończonych, choć w wielu aspektach niezwykle dopracowanym projekcie Hitchcocka. Dla wprowadzenia przejrzystości konieczne jest zdefiniowanie i zawężenie enigmatycznego poję-

\footnotetext{
2 Zob. The Pervert's Guide to Cinema, reż. S. Žižek, 2006.
} 
cia „dzieła nieukończonego”, tak aby zachować ścisłość analiz w dalszej części wywodu. Ze względu na złożoność tego zagadnienia najwłaściwszym krokiem wydaje się sięgnięcie do słów samego Hitchcocka, który często w swoich artykułach, esejach oraz prywatnych pismach posługiwał się pojęciem „filmów, które moglibyśmy zrobić" (Films We Could Make - tytuł znanego eseju Hitchcocka z 1927 roku $^{3}$ ), oraz „filmów, które chciałbym zrobić” (Films I'd Like to Make), a niekiedy również w negatywnej formie - „filmów, których cenzorzy by nie przepuścili" (Films the censor wouldn't pass) ${ }^{4}$. Hitchcockowi doskwierały ograniczenia nakładane nań przez studia, krytyków, a niekiedy również przez samą widownię; to do tych ludzi i instytucji odnosił się zbiorczo, mówiąc i pisząc o „nich” - tych, którzy uniemożliwiają mu zajmowanie się tematami, które najbardziej go interesowały. Podążając za Hitchcockiem, za nieukończone dzieło będę uważał projekt filmu, który został przygotowany do produkcji, ale nie uzyskał aprobaty (i finansowania) producentów. W takim ujęciu dzieło nieukończone (niewyprodukowane) jest kompletne w zamyśle reżysera, który zebrał materiały, przemyślał techniki oraz zaakceptował scenariusz. Ponieważ mowa tu o zamysłach, tekstach, fotografiach i stosunkowo niedużej ilości nakręconego materiału próbnego, wydaje się, że najbardziej pojemnym, a zarazem precyzyjnym terminem będzie słowo ,projekt”, toteż właśnie nim będę się tutaj posługiwał.

Projekt Kalejdoskopu pochłonął Hitchcocka bez reszty, na pewnym etapie jawił mu się jako kolejny wielki sukces. Niestety, natrafił na opór niemal z każdej strony. Rodzi się zatem szereg pytań: co sprawiło, że akurat ten projekt został okrzyknięty zbyt śmiałym i obrazoburczym? Jakie są związki tego zamysłu z dotychczasowym dorobkiem reżysera? I wreszcie - czy gdyby został zrealizowany, film ten istotnie mógłby okazać się jednym z najważniejszych dzieł w dorobku Hitchcocka? Sidney Gottlieb, znany biograf Hitchcocka, w jednym ze swoich esejów poświęconych nieukończonym dziełom reżysera wysuwa sugestię istnienia kilku kategorii takich projektów: te, które od początku skazane były na nieukończenie (chodzi o filmy, których los był przesądzony ze względu na czas, w jakim miały powstać); te, które „osiągnęły niekompletność” (chodzi o filmy niebudzące wątpliwości na etapie konceptu, jednak rozwijające się w kierunku, który skazywał je na odrzucenie przez wytwórnię lub porzucenie przez samego reżysera); wreszcie takie, które zostały ,pchnięte” ku nieukończeniu (na ogół przez splot wydarzeń, niezrozumienie ze strony innych filmowców lub brak środków) ${ }^{5}$.

Interesujące jest zatem pytanie: do której z tych kategorii zaliczyć można Kalejdoskop? Ponieważ materiał badawczy jest niewielki i rozproszony wśród prywatnych kolekcjonerów, w zbiorach muzealnych oraz archiwach wytwórni,

3 A. Hitchcock, Films We Could Make, [w:] Hitchcock on Hitchcock, red. S. Gottlieb, Berkeley 1995, s. 165-168.

4 S. Gottlieb, Unknown Hitchcock: The Unrealized Projects, [w:] Hitchcock: Past and Future, red. R. Allen, S. Ishii-Gonzales, London 2004, s. 90-91.

5 Ibidem, s. 91. 
skupiłem się przede wszystkim na dwóch — dostępnych we fragmentach — wersjach scenariusza oraz materiale próbnym udostępnionym w internecie. Notatki, uwagi oraz korespondencja Hitchcocka, które odnoszą się do tego projektu, zostały przytoczone za biografami i badaczami powołującymi się na dostęp do nich. Należy pamiętać, że materiały, o których mowa, nie były dotychczas analizowane w całości, stąd brak kompleksowych źródeł referencyjnych dla weryfikacji tez wysuwanych przez niektórych badaczy.

Już kwestia tytułu nastręcza pewnych trudności, w literaturze funkcjonują bowiem dwa, które przypisuje się rzeczonemu projektowi: Szat (Frenzy) oraz Kalejdoskop (Kaleidoscope), niekiedy nawet: Frenzy/Kaleidoscope. Ta myląca sytuacja wynika z częstego łączenia późniejszej, udanej produkcji filmu Szał (Frenzy, 1972) z pomysłem rozwijającym niektóre wątki i motywy Psychozy, który według większości źródeł pojawił się u Hitchcocka około 1965 roku, a który miał nosić tytuł Kalejdoskop (Kaleidoscope) ${ }^{6}$. Wśród niektórych historyków i filmoznawców, takich jak Gottlieb, Witty czy White, funkcjonuje przekonanie, że późniejsza produkcja Szału była przedłużeniem wcześniejszych nieudanych prób z produkcją Kalejdoskopu. Istotnie, można doszukać się tutaj pewnych paraleli, szczególnie na poziomie fabularnym, niemniej jednak Szał ma w sobie bardzo niewiele z oryginalności i śmiałości Kalejdoskopu ${ }^{7}$. Rzeczywista historia tego niezwykłego projektu zaczęła się około 1964 roku, kiedy Hitchcock zarejestrował w Gildii Scenarzystów (Writer's Guild of America) pomysł na scenariusz filmowy oparty na historii dwóch brytyjskich seryjnych morderców z lat czterdziestych: Neville'a Heatha i Johna George'a Haigha. Według pierwotnego zamysłu reżysera miał to być rodzaj prequelu do Cienia watpliwości (Shadow of a Doubt, 1943) - filmu, który skupiał się na historii niejakiego Josepha Cottena nazywanego „wesołym mordercą wdów”. Fabuła tego filmu (uznawanego wówczas za bardzo śmiały) oscylowała wokół motywu seryjnego mordercy, jednak ze względu na ograniczenia kodeksu Haysa w latach czterdziestych nie pokazano w nim żadnej ze zbrodni ani elementów związanych z ich seksualnym podłożem ${ }^{8}$. Hitchcock uważał, że w latach sześćdziesiątych, zwłaszcza po sukcesie Psychozy, będzie mógł posunąć się o wiele dalej, a widzowie oczekują od niego śmiałości. Niektórzy badacze (szczególnie Gottlieb) uważają, że Kalejdoskop miał być swoistą filmową psychoanalizą seryjnego mordercy, skupiającą się na jego seksualności i ukazującą cały proces „uwodzenia”, wabienia i mordowania, jednocześnie podkreślając psychologiczną złożoność motywów. Innowacyjny charakter tego pomysłu wynikał przede wszystkim z faktu, że morderca miał zostać protagonistą, a cała narracja miała być prowadzona na wzór strumienia świadomości. Jak się później okazało, właśnie nowatorstwo w ukazywaniu psychologii sprawcy stało

6 S. Witty, The Alfred Hitchcock Encyclopedia, Lanham 2016, s. 203.

7 Ibidem.

8 G. Adair, Alfred Hitchcock: Filming Our Fears, Oxford 2002, s. 77-79. 
się jednym z kluczowych czynników, które uśmierciły ten projekt. Złożony w Gildii Scenarzystów zamysł fabularny był bardzo luźny i skupiał się na postaci brutalnego, seryjnego mordercy, który wykorzystuje swoje walory fizyczne (miał być kulturystą lub sportowcem), aby uwodzić i następnie mordować kobiety. Hitchcock chciał, by motywacja sprawcy była jednoznacznie seksualna, a jego działanie bezwzględnie brutalne. Wzajemne przenikanie się brutalności i seksualności miało tworzyć unikatowy, „pornograficzny” rodzaj narracji psychologicznej. Dan Auiler, autor Hitchcock's Secret Notebooks, który badał nakręcony materiał próbny, widzi w tej produkcji dzieło przełomowe, które całkowicie zrewolucjonizowałoby amerykańskie kino i niewątpliwie wyprzedzało swoje czasy o całe dekady9

Początkowo Hitchcock zwrócił się do Roberta Blocha, autora powieściowego pierwowzoru Psychozy z 1959 roku, aby ten napisał utwór literacki oparty na zamyśle reżysera, który następnie będzie mógł zostać zaadaptowany na potrzeby filmu. Może się to wydawać dziwne, ale Robert Bloch nie poradził sobie z zaproponowanym mu materiałem, uważał go także za zbyt brutalny, a wątki erotyczne wydawały mu się zbyt niepokojące ${ }^{10}$. Rezygnacja Blocha, znanego autora literatury sensacyjnej, przyczyniła się do szybkiego otoczenia pomysłu Kalejdoskopu nimbem dzieła „zbyt szokującego” i „zbyt śmiałego”. Oprócz Blocha propozycja współpracy literackiej trafiła również do Samuela Taylora, Aleca Coppela i Hugh Wheelera, wszyscy jednak albo odmawiali, albo nie byli w stanie porozumieć się $\mathrm{z}$ reżyserem.

Następnie Hitchcock zwrócił się do Benna Levy'ego, z którym pracował już wcześniej przy filmie Szantaż (Blackmail, 1929). Levy nie miał większych oporów przed przystąpieniem do pracy nad materiałem zaprezentowanym mu przez Hitchcocka. W liście do reżysera, odwołując się do psychologicznej konstrukcji postaci głównego bohatera, napisał: ,ironiczny wydaje się fakt, że to po prostu mały chłopiec, który nie radzi sobie z życiem”. W tym samym liście zaproponował również, aby film zatytułować właśnie Mały chtopiec (Little Boy) ${ }^{11}$. Ta sugestia spodobała się Hitchcockowi i może okazać się bardzo cenną wskazówką przy próbie rekonstrukcji jego oryginalnych pomysłów. Protagonista miał nazywać się Willie Cooper; powierzchownie miał przypominać typowego Hitchcockowskiego „sympatycznego" złoczyńcę: przystojny, inteligentny, elegancki, z nienagannymi manierami. Film miał zawierać dwie brutalne sceny morderstw oraz zaskakujący finał. Pierwsza ofiara, Caroline Varley, miała być pracownicą ONZ, która ginie w Central Parku (scena została częściowo zrealizowana na potrzeby materiału próbnego $)^{12}$. Wydaje się, że scena zabójstwa Caroline, w której główny bohater jest półnagi, a ciało ofiary niemal całkowicie obnażone, miała służyć jako kla-

9 D. Auiler, op. cit., s. 431.

$10 \mathrm{http}: / /$ mysterymanonfilm.blogspot.com/2009/02/murder-scene-written-by-hitchcock.html (dostęp: 3 listopada 2018).

11 Ibidem.

12 Ibidem. 
syczne, Hitchcockowskie „trzęsienie ziemi” - scena otwierająca, która w sposób szokujący dla widza demaskuje protagonistę jako mordercę i drapieżnika seksualnego. Kolejna ofiara, Patti Landis, została przedstawiona jako studentka szkoły artystycznej, a w scenariuszu celowo podkreślona została jej niewinność i nieśmiałość. Uroda i czar bohatera miały imponować Patti i czynić ją podatną na jego manipulacje. Willie z premedytacją i wyrachowaniem uwodzi ją w perwersyjnej, podszytej erotyką grze. Głównym źródłem suspensu w zamyśle scenarzysty miała być właśnie owa gra między mordercą a nieświadomą ofiarą — widz wie, kim jest główny bohater, i zdaje sobie sprawę, dokąd zmierza rozwijający się wątek romansu, oczekuje nieuchronnego końca i zastanawia się, jak i gdzie dojdzie do kolejnej zbrodni. Źródłem grozy jest cynizm, z jakim morderca odnosi się do uwodzonej przez siebie kobiety, rozbudzając w niej prawdziwe uczucia i traktując jak osaczaną zdobycz. Scena morderstwa Patti została pomyślana jako pościg mordercy za ofiarą, która w ostatniej chwili orientuje się w grożącym jej niebezpieczeństwie. Po dokonaniu drugiej zbrodni wprowadzona zostaje kolejna ważna postać: policjantka, która ma odegrać rolę „przynęty”. Morderca rzeczywiście wybiera ją na kolejną ofiarę, a następnie autentycznie się w niej zakochuje. W zamyśle scenarzysty wątek ten miał być swego rodzaju „mroczną historią miłosną", odwracającą klasyczne narracje tego typu - lojalność wobec prawa i moralność policjantki zostaną wystawione na próbę, na równi z kompulsywną potrzebą zabijania, którą zabójca będzie usiłował przezwyciężyć ze względu na prawdziwe uczucia, jakie się w nim rodzą ${ }^{13}$.

W latach sześćdziesiątych niemal każdy z opisanych powyżej pomysłów fabularnych objęty był tabu. Szczególnie przemoc, seks, nagość, ale — jak się okazało - również ,humanizowanie" mordercy. Niewątpliwie scenarzysta (podobnie jak Hitchcock) był zainteresowany psychologią sprawcy, chciał, by był on postacią złożoną i trudną do jednoznacznego potępienia. Można przypuszczać, że zamierzał posunąc się dalej niż w wypadku postaci Normana Batesa, który miał w sobie pewną dozę uroku i budził pozytywne uczucia widzów. W tej wersji scenariusza bohater został pomyślany jako czarujący, autentycznie uwodzicielski, inteligentny mężczyzna, który mógł budzić sympatię na równi z lękiem. Jego zbrodnie miały mieć do pewnego stopnia incydentalnych charakter - nie niszczyć całkowicie jego humanizmu. Niestety, gotowy scenariusz autorstwa Levy'ego nie spotkał się z entuzjastycznym przyjęciem, sam Hitchcock wspomina go jako „bardzo nieudany”. Zdaniem biografów uważał on, że historia jest pełna klisz i powiela poruszane już wcześniej wątki. Niewątpliwie miał obawy, których źródłem były wspomniane już dwa wcześniejsze filmy (Marnie i Zerwana kurtyna), przyjęte chłodno i uznane za wtórne. Ostatecznie reżyser zrezygnował ze współpracy z Bennem Levym ${ }^{14}$.

13 Ibidem.

14 D. Auiler, Hitchcock Lost: The Lost Silent and Frenzy 67, Los Gatos 2013, s. 44-45. 
Po tym niepowodzeniu Hitchcock zwrócił się do Howarda Fasta, znanego już wówczas pisarza i scenarzysty, zdecydował się również wprowadzić poważne zmiany do pierwszego szkicu scenariusza autorstwa Levy' ego $^{15}$. Ten fakt należy uznać za istotny, wcześniej bowiem tylko raz Hitchcock zaangażował się bezpośrednio w pisanie scenariusza do swojego filmu i było to w 1947 (Akt oskarżenia, Paradine Case $)^{16}$. W nowej wersji scenariusza, nad którą pracował razem z Fastem (znanym niestety jedynie we fragmentach), reżyser wprowadził istotne i śmiałe innowacje w konstrukcji i motywacji bohatera. Pojawił się wątek kulturystyki i narcyzmu; Willie miał kolekcjonować magazyny kulturystyczne (co było wyraźną sugestią homoseksualizmu; w tamtych czasach magazyny tego rodzaju często bywały homoerotyczne) ${ }^{17}$. Wydaje się, że wprowadzenie tego elementu mogło służyć pogłębieniu portretu psychologicznego bohatera i komplikacji jego motywów. Hitchcock wprowadził nawet scenę, w której matka Williego (w tej wersji bohater miał z nią mieszkać) wchodzi do pokoju, gdy ten onanizuje się w trakcie ćwiczeń. Fizyczna strona bohatera, która ulega sublimacji w narcystycznej obsesji na punkcie własnego ciała, mogła stanowić interesujący składnik jego patologicznej osobowości. W tym miejscu można pokusić się o dokonanie pewnej ekstrapolacji tego zamysłu w oparciu o elementy psychoanalizy (niewątpliwie ważnej inspiracji dla Hitchcocka). Willie jest zatem homoseksualistą, ale nie akceptuje swojej seksualności i za wszelką cenę usiłuje ją wyprzeć; jednocześnie pragnie być podziwiany, chce, aby jego praca nad własnym ciałem była doceniana, co jest dla niego źródłem perwersyjnej gratyfikacji seksualnej. Morderstwa, których dokonuje, są refleksami jego autodestrukcyjnej, desperackiej chęci wpisania się w heteronormatywną rzeczywistość. Zabija on kobiety w pewnym sensie z rozpaczy, chcąc odczuwać wobec nich takie pożądanie, jakim one obdarzają jego, gdy je uwodzi. Jest człowiekiem pękniętym, niekompletnym, pozbawionym empatii - osobowością psychopatyczną. Jeśli ta ekstrapolacja odpowiada zamysłom Hitchcocka, Willie Cooper byłby pierwszym autentycznie sportretowanym seryjnym mordercą w historii kina, bez przerysowań i niepotrzebnych uproszczeń. W tej wersji scenariusza pojawiła się jednak problematyczna kwestia wątku policjantki i prawdziwego uczucia, jakie łączy ją i mordercę. Wydaje się, że reżyser nie zdołał rozwiązać tego problemu, a w dostępnych źródłach często wspomina się o problemie trzeciej części filmu (najprawdopodobniej odnosząc się właśnie do tego wątku).

W tym miejscu należy również przypomnieć pierwotne inspiracje postaciami prawdziwych seryjnych morderców: Neville'a Heatha, psychopatycznego angielskiego mordercy z 1946 roku, Johna George’a Haigha, który rozpuszczał swoje

15 P. Ackroyd, Alfred Hitchcock, New York 2015, s. 122.

16 G. Perry, The Films of Alfred Hitchcock, Worthing 1965, s. 90-99.

$17 \mathrm{http} / / /$ www.bbc.com/culture/story/20180620-why-hitchcocks-kaleidoscope-was-too-shocking-to-be-made (dostęp: 3 listopada 2018). 
poćwiartowane ofiary w kwasie, oraz Johna Reginalda Christiego, który wykazywał skłonności nekrofilskie. Nie jest jasne, ile z tych przerażających inspiracji znalazłoby swoje miejsce w ostatecznej wersji filmu, niemniej Hitchcock rozważał wprowadzenie wątków inspirowanych tymi postaciami. W zgłoszeniu, które złożone zostało w Gildii Scenarzystów w 1964 roku, znajdują się szczegółowe opisy działalności Haigha i Christiego. Zostały w nim wyraźnie zaznaczone i opisane zarówno motywy rozczłonkowywania zwłok, jak i nekrofilii. W zgłoszeniu tym znajduje się również zdanie, że ewentualny scenariusz nie będzie skupiał się na tego rodzaju „odrażających" detalach ${ }^{18}$. Wydaje się jednak oczywiste, że skoro pierwotna wersja scenariusza autorstwa Levy'ego została uznana za zbyt sztampową, a intencją reżysera było przezwyciężenie ograniczeń ówczesnego kina, naturalnym było zwrócenie się ku elementom obecnym w założeniach tego projektu od samego początku.

W kontekście portretu psychologicznego bohatera niewątpliwie interesujący jest wątek nekrofilii. Samo pojęcie nekrofilii należy przy tym rozumieć zgodnie z rozważaniami Ericha Fromma wyłożonymi w słynnym tekście Agresja złośliwa: nekrofilia (z tomu Anatomia ludzkiej destrukcyjności). Autor rozróżnia w nim dwa poziomy tego zjawiska, mogące funkcjonować niezależnie od siebie lub w powiązaniu: (1) nekrofilię seksualną, która najczęściej kojarzona jest z tym pojęciem w powszechnej świadomości, a która odnosi się do odczuwania pociągu seksualnego do zwłok ludzkich oraz czerpania satysfakcji seksualnej z kontaktu z nimi; a także (2) nekrofilię nieseksualną, która obejmuje cały szereg zachowań związanych z fetyszyzowaniem zwłok, pragnieniem posiadania części martwego ciała oraz rozczłonkowywania i okaleczania zwłok ${ }^{19}$. W wypadku bohatera Kalejdoskopu Hitchcock najprawdopodobniej rozważał wprowadzenie nieseksualnej formy, być może w postaci zbliżonej do nekrofilitycznego fetyszyzmu Normana Batesa, który przechowywał zmumifikowane ciało swojej matki w piwnicy motelu. Skłonności nekrofilskie Williego Coopera nie miałyby powiązania z seksualizmem, występowałyby natomiast $\mathrm{w}$ aktach czystej destrukcji. Najprawdopodobniej dokonywałby on aktów rozczłonkowywania swoich ofiar, być może w (do pewnego stopnia) zrytualizowany sposób, a następnie rozpuszczałby je w kwasie lub pali2 ${ }^{20}$.

Ciekawym pytaniem wydaje się, czy reżyser planował powiązać sam akt zabijania z jakąś formą podniecenia seksualnego, co zgodnie z założeniami Fromma również może zostać uznane z zachowanie nekrofilskie (Fromm nazywał to „namiętnością do przekształcania żywego w martwe”) ${ }^{21}$. Willie Cooper mógł być twórczym rozwinięciem postaci Normana Batesa, przesuwającym granice tego,

18 http://www.writingwithhitchcock.com/frenzy.html (dostęp: 5 listopada 2018).

19 E. Fromm, Anatomia ludzkiej destrukcyjności, przeł. J. Karłowski, Poznań 1998, s. 366-371.

20 Ibidem.

21 Ibidem, s. 371. 
co może zostać ukazane na ekranie, i ukazującym mordercę nie tylko w chwili dokonywania zbrodni, ale również post factum. Trudno dziś wyobrazić sobie, jak bardzo szokujący wydawał się taki koncept w latach sześćdziesiątych, nawet po sukcesie Psychozy, która, siłą rzeczy, musi pozostać punktem odniesienia dla tego projektu. Jak pamiętamy, w Psychozie Hitchcock skupił się na samym akcie zbrodni, unikał pokazywania zwłok, nadmiernej ilości krwi, a nawet ograniczał kontakt sprawcy i martwego ciała ofiary do niezbędnego minimum. W ujęciach następujących po piwotalnej scenie morderstwa pod prysznicem widzimy, jak Norman Bates przenosi zwłoki (kamera ich nie pokazuje), następnie sprząta miejsce zbrodni, myje ręce i zawija ciało w folię (całkowicie zakrywając je przed widzem); dopiero w takiej postaci zwłoki zostają przeniesione do bagażnika samochodu, by wreszcie utonąć w bagnie. Sceny te zostały nakręcone niemal „sterylnie", czynności mordercy są metodyczne, nie wykazuje on żadnych emocji, a cała sekwencja trwa stosunkowo krótko. Analizując materiał próbny przygotowany na potrzeby Kalejdoskopu, można przypuszczać, że to właśnie martwe ciała byłyby jednym z kluczowych elementów analogicznych scen w tym filmie. Ciało ofiary przedstawione $\mathrm{w}$ zrealizowanej scenie morderstwa zostało w pewnym sensie uwypuklone jako motyw (poprzez swoją nagość), reżyser zastosował również zbliżenia, ukazując zadane ofierze rany oraz szczegóły anatomiczne. Konstrukcja sceny podkreśla, że morderca nie zadał sobie trudu, by okryć nagie ciało ofiary, nie interesowało go ukrywanie jej tożsamości, był zadowolony z tego, czego dokona $^{22}$. Takie podejście można uznać za próbę wprowadzenia konwencji naturalistycznej do gatunku, na długo przed pierwszymi horrorami, które później zostaną okrzyknięte przełomowymi slasherami: Teksańska masakra pita mechaniczna (The Texas Chain Saw Massacre, reż. T. Hooper, 1974), Halloween (Halloween, reż. J. Carpenter, 1978) oraz Piatkiem, trzynastego (Friday the $13^{\text {th }}$, reż. S. Cunningham, 1980).

Obraz mordercy, jaki wyłania się z przedstawionych powyżej rozważań, jest złożony i interesujący. Hitchcock zaproponował wieloaspektową, wnikliwą analizę psychologii sprawcy, której nie można jednak jednoznacznie sklasyfikować jako patologicznej (tak jak miało to miejsce w wypadku Normana Batesa). Choroba psychiczna bohatera Psychozy służyć mogła jako element upraszczający, tłumaczący jego zbrodniczą działalność stanem, na który sprawca nie ma wpływu. Syndrom rozszczepienia osobowości był przy tym efektownym narzędziem narracyjnym ukazującym mordercę jako ofiarę własnego szaleństwa. Badania pokazują jednak, że mordercy, a zwłaszcza seryjni mordercy, bardzo rzadko cierpią na choroby psychiczne (takie jak paranoja, schizofrenia, choroba afektywna dwubiegunowa, czy też zaburzenie dysocjacyjne osobowości) ${ }^{23}$. W powszechnej

22 D. Auiler, Hitchcock's Secret Notebooks..., s. 435.

23 J. Levin, J.A. Fox, Normalcy in Behavioral Characteristics of the Sadistic Serial Killer, [w:] Serial Murder and the Psychology of Violent Crimes, red. R.N. Kocsis, New York 2008, s. 4-5, 10. 
świadomości często daje się zaobserwować tendencję do asocjacji zachowań socjopatycznych oraz działalności morderców z patologią psychiczną, co pozwala w jakiś sposób zrozumieć okrucieństwo ich zachowań. Nie jest jasne, czy Hitchcock rozważał wprowadzenie wątku homoseksualizmu głównego bohatera, traktując go jako „chorobę psychiczną” (należy pamiętać, że Amerykańskie Towarzystwo Psychiatryczne dopiero w 1974 roku zdecydowało o usunięciu homoseksualizmu z listy chorób psychicznych), z całą pewnością był człowiekiem zbyt inteligentnym, by hołdować takim uproszczeniom. Nie ulega jednak wątpliwości, że Willie Cooper miał być w zamyśle Hitchcocka postacią dużo mroczniejszą, niż pierwotnie zakładał Levy w swojej wersji scenariusza. Reżyser chciał zerwać z motywem mordercy eleganckiego, budzącego sympatię i zmusić widza do obcowania z ,prawdziwym potworem”. Wątki homoseksualne nie były Hitchcockowi obce i pojawiały się w wielu filmach, choć zazwyczaj nie były przedstawiane wprost, a raczej sugerowane. Niektórzy badacze zwracają uwagę na dość wyraźne traktowanie skłonności homoseksualnych jako elementu patologicznego, niejako predestynującego do popełnienia zbrodni. Typowym przykładem takich właśnie kryptohomoseksualnych bohaterów jest para morderców z Liny (Rope, 1948), wujek Charlie z Cienia watpliwości (Shadow of a Doubt) czy panna Danvers z Rebeki (Rebecca, 1940) ${ }^{24}$. Wszystkie te postacie skrywają sekret swojej seksualności i przez to same stają się tajemnicze i nabierają mrocznych cech.

Jednym z ważniejszych czynników, które wpłynęły na historię projektu $\mathrm{Ka}$ lejdoskopu, była korespondencja pomiędzy Hitchcockiem a François Truffautem. W roku 1967 filmowców łączyła już przyjaźń, która zaczęła się pięć lat wcześniej, kiedy Truffaut przeprowadził z Hitchcockiem wywiad rzekę, w istocie mający postać rozmów dwóch reżyserów na temat kina. Mimo niedużego dorobku Truffaut był już wówczas znanym autorem francuskiej Nowej Fali i wschodzącą gwiazdą europejskiego kina. Hitchcock był, rzecz jasna, powszechnie uznawany za wybitnego reżysera, autora hitów kinowych, jednak raczej twórcę kina popularnego i specjalistę od rozrywki dla masowej publiczności. Rozmowy z Truffautem, które ukazały się drukiem w 1966 roku, pomogły zmienić to wrażenie i ugruntować pozycję, która z dzisiejszej perspektywy wydaje się oczywista i niepodważalna: wybitnego autora, wielkiego stylisty i genialnego technicznie twórcy ${ }^{25}$. Intensywna wymiana korespondencji trwała aż do śmierci Hitchcocka w 1980 roku. Wydaje się, że miał on duże zaufanie do gustu i artystycznego wyczucia Truffauta, uważał go za jednego z niewielu współczesnych mu reżyserów, którzy rozumieją kino podobnie jak on i obdarzeni są zbliżoną wyobraźnią wizualną. Nie dziwi zatem, że jedna z wersji scenariusza została przesłana do Truffauta z prośbą o opinię i sugestię ewentualnych korekt.

24 P. White, Hitchcock and Hom(m)osexuality, [w:] Hitchcock: Past and Future..., s. 212.

25 J.E. Haynes, Truffaut-Hitchcock, [w:] A Companion to François Truffaut, red. A. Dudley, A. Gillain, Hoboken 2013, s. 265-283.

Prace Kulturoznawcze 22, 2018, nr 3

(C) for this edition by CNS 
Hitchcock, który był już głęboko zaangażowany w ten projekt, zapewne nie spodziewał się krytycznej reakcji. Truffaut doceniał co prawda narracyjne i plastyczne walory scenariusza oraz techniczną stronę projektu, jednak tematyka, a szczególnie postać głównego bohatera zostały przez niego skrytykowane ${ }^{26}$. Uważał, że gotowy film, mimo nowatorstwa, balansowałby na granicy pornografii, a postać głównego bohatera nie budzi żadnych pozytywnych emocji widza, co miałoby zły wpływ na recepcję filmu.

Biografowie Hitchcocka mają zastanawiającą tendencję do wyolbrzymiania negatywnej reakcji Truffauta, w rzeczywistości należy ją scharakteryzować raczej jako sceptyczną, a nie negatywną. W cytowanej już książce Hitchcock's Secret Notebooks Dan Auiler przytacza w całości list z odpowiedzią Truffauta. Oprócz zwrócenia uwagi na elementy seksualne i przemoc Truffaut pisze również, że nie martwią go one, ponieważ ma zaufanie do kunsztu Hitchcocka i wie, że nie będzie on pochylał się nad zbędnymi szczegółami. Można przypuszczać, że Truffaut argumentował, opierając się na stylu i technice zastosowanych w wypadku Psycho$z y$, gdzie motywy seksu i przemocy łączyły się w fabule pełnej suspensu, a strona wizualna filmu była utrzymana w typowej dla Hitchcocka eleganckiej estetyce (stanowiącej również reminiscencję wcześniejszego okresu w historii amerykańskiego kina). We wcześniejszych dziełach Hitchcocka precyzja techniczna i estetyka wizualna wpływały na woalowanie brutalności fabuł i wprowadzały pewną równowagę, ułatwiającą widzowi odbiór szokującej treści. W proponowanej wersji Kalejdoskopu wątki te zostały jednak obnażone i uwypuklone poprzez fakt, że morderca został uczyniony protagonistą; ich jaskrawość byłaby tak uderzająca, że mogłaby przytłoczyć nieprzygotowanego widza lat sześćdziesiątych i zamiast efektu grozy i suspensu spowodować obrzydzenie ${ }^{27}$. Truffaut uważał zapewne, że Hitchcock nie posunie się do całkowitego zerwania ze swoim wcześniejszym, konsekwentnie rozwijanym stylem.

Innym ciekawym i nowatorskim aspektem projektu Kalejdoskopu miała być jego strona techniczna i wizualna. Już wprowadzająca, tytułowa sekwencja, nawiązująca stylistycznie do kalejdoskopu i pokazująca postać mężczyzny — która przekształca się nieustannie $\mathrm{w}$ feerii intensywnych, psychodelicznych, pulsujących barw, niczym w kalejdoskopowym rozszczepieniu — budzić mogła w owym czasie zdumienie ze względu na skomplikowaną technikę zdjęć. Za bezpośrednie stylistyczne inspiracje reżysera uznaje się dziś przede wszystkim słynne Powiększenie (Blowup, reż. M. Antonioni, 1966), które okazało się wielkim sukcesem, szczególnie wśród młodej widowni. Hitchcock był pod ogromnym wrażeniem technicznej precyzji włoskiego kina i pomysłowości jego twórców w poszukiwaniu nowego języka wizualnego. Interesowała go stylistyka neorealistycznego kina włoskiego, a także francuskiej Nowej Fali; można tu wskazać chociażby filmy

26 P. McGilligan, Alfred Hitchcock: A Life in Darkness and Light, New York 2003, s. 646.

27 Ibidem. 
Jeana-Luca Godarda. Kolejnym, ważnym źródłem inspiracji były także pewne wzorce z cinéma-vérité ${ }^{28}$. Film miał być kręcony w plenerach, przy naturalnym oświetleniu, z zastosowaniem mobilnych kamer i ujęć „z ręki”, dzięki czemu możliwe byłoby uzyskanie niestandardowych kątów i wrażenia dynamicznego ruchu w subiektywnych ujęciach. Hitchcok chciał, żeby cały film został nakręcony w kolorze, interesowały go także eksperymenty z kolorystyką przy wykorzystaniu najnowszych klisz i formatów ${ }^{29}$.

Zastosowanie tego rodzaju technik przy kręceniu scen morderstw niewątpliwie musiało robić ogromne wrażenie, widzowie (oraz producenci) nie byli wówczas przyzwyczajeni do tego poziomu realizmu. Hitchcock spędził trzy miesiące, wyszukując i testując lokalizacje w Nowym Jorku, ostatecznie zdecydował się na Central Park, Stadion Shea oraz doki rezerwowe US Navy ${ }^{30}$. Reżyser starał się znaleźć plenery, które będzie można maksymalnie wykorzystać: chodziło o możliwość nakręcenia dramatycznych scen pościgu mordercy za ofiarą oraz interesujące warunki związane z oświetleniem i konstrukcją planu. Ważna była także obecność wody, która miała być w tym projekcje swoistym lejtmotywem (co ponownie przywodzi na myśl powiązania z Psychoza). Z korespondencji reżysera z Bennem Levym wynika, że to on podsunął mu ten pomysł. W biografii Hitchcocka John Russell Taylor przytacza pytanie, które ten miał zadać Levy'emu: „Czy nie uważasz, że w tej historii jest sporo wody?" (Don't you think there's rather a lot of water in this story?) ${ }^{31}$. Motyw ten, który mógł zrodzić się zupełnie przypadkowo, okazał się bardzo użytecznym narzędziem wizualnym. Przykładem może być scena zrealizowana na potrzeby materiału próbnego, w której ofiara leży w strumieniu, podczas gdy morderca stoi nad jej ciałem. Usytuowanie kamery pod ostrym kątem stóp sprawcy dramatycznie uwypukla jego wyciągniętą rękę, w której trzyma nóż. Zarówno morderca, jak i ofiara są mokrzy, z narzędzia zbrodni kapie woda i krew, efekt przywodzi na myśl scenę z Psychozy, w której widzimy spływającą do odpływu, zmieszaną z wodą krew zamordowanej pod prysznicem ofiary. Konstrukcja nakręconych próbnie scen nie pozostawia wątpliwości co do precyzji, z jaką reżyser przygotowywał się do realizacji tego projektu. Howard Fast wspominał, że do momentu ukończenia drugiej wersji scenariusza Hitchcock sprecyzował ponad czterysta pięćdziesiąt ustawień kamery ${ }^{32}$. Zrealizowana scena morderstwa zaczyna się od szerokich, statycznych ujęć, które wprowadzają widza w plener i kreślą wizualne tło. Następnie, sukcesywnie przechodzimy do planu średniego, ukazującego mordercę i ofiarę; kamera pracuje płynnie, przedziera się przez zarośla, spoglądając poprzez listowie. W chwili popełniania zbrodni stosowane są zbliżenia (niekiedy również detale) i niemal wyłącznie ujęcia „z ręki”;

\footnotetext{
28 J. Orr, Hitchcock and Twentieth-century Cinema, New York 2005, s. 9-10.

29 D. Auiler, Hitchcock's Secret Notebooks..., s. 443-445, 547-548.

30 J. Russell Taylor, Hitch: The Life and Times of Alfred Hitchcock, Cambridge, MA 1978, s. 295.

31 Ibidem.

32 D. Spoto, The Dark Side of Genius: The Life of Alfred Hitchcock, Cambridge, MA 1999, s. 541.
}

Prace Kulturoznawcze 22, 2018, nr 3

(C) for this edition by CNS 
kamera dynamicznie przeskakuje między punktem widzenia mordercy i nietypowymi kątami, obraz drży, momentami jest nieostry, podkreśla dynamizm i dramatyzm sceny. Chlapiąca, rozbryzgiwana woda odgrywa tutaj ciekawą funkcję, uzupełniając i potęgując ekspresję ujęć. Z perspektywy dzisiejszego widza, przyzwyczajonego do różnorodności stylów i technik stosowanych we współczesnym kinie, opis ten może nie budzić wielkiego zdumienia, jednak w latach sześćdziesiątych nietypowe ujęcia i plany oraz naturalistyczna estetyka stanowiły nie tylko novum, ale również, potencjalnie, źródło silnych emocji widowni. Ciekawy jest także fakt, że Hitchcock planował zaangażować zupełnie nieznanych aktorów, zależało mu bowiem na maksymalizacji naturalistycznego efektu. Gwiazdy kina o ugruntowanej pozycji i określonej charyzmie ekranowej z pewnością odciągałyby uwagę od szokującej materii filmu (o czym zresztą Hitchcock sam pisał w swoich esejach). Nawet zaangażowani do zdjęć próbnych statyści do dziś pozostają zupełnie anonimowi ${ }^{33}$.

Kilkunastominutowy materiał nakręcony na $16 \mathrm{~mm}$ taśmie (do dziś zachowała się nieco ponad minuta), seria fotosów oraz szkic scenariusza zostały ostatecznie przedłożone dyrekcji MCA/Universal w 1967 roku. Hitchcock był przekonany, że zdoła nakłonić producentów do sfinansowania tego projektu, który okrzyknął swoim „dziełem autorskim”. Z jego kontraktu wynikało, że ma dowolność w doborze tematów, technik i realizacji projektów o budżecie nieprzekraczającym trzech milionów dolarów (w założeniu Kalejdoskop miał kosztować około jednego miliona $)^{34}$. Biorąc pod uwagę przedstawione powyżej fakty oraz przytoczoną reakcję Truffauta, nie powinno dziwić, że dyrekcja studia niemal natychmiast odrzuciła cały materiał i uznała projekt nie tylko za zbyt śmiały i kontrowersyjny, ale także szokująco pornograficzny. Szczególny opór budziła koncepcja mordercy jako głównego bohatera - producenci byli przekonani, że protagonista, który nie budzi żadnej sympatii widza, skaże film na niechybną porażkę. Ponieważ dwa wcześniejsze filmy Hitchcocka można było uznać za nieudane, ryzyko dla studia było zbyt duże. Producenci obawiali się także zerwania z dotychczasową manierystyczną stylistyką filmów Hitchcocka oraz motywem „eleganckiego mordercy”, które były swoistym „znakiem firmowym” reżysera i zazwyczaj gwarantowały sukces ${ }^{35}$. Hitchcock przyjął tę odmowę bardzo źle — uważał, że został całkowicie niezrozumiany jako artysta, a reakcja studia odzwierciedla wszystko, z czym chciał zerwać w amerykańskim kinie. $Z$ poczuciem klęski i z typową dla siebie obcesowością szukał również kogoś, kogo mógłby bezpośrednio winić za to niepowodzenie. Jego wybór padł na Howarda Fasta, z którym zerwał znajomośćc ${ }^{36}$. Wspomniana już wcześniej produkcja Szału z 1972 roku mogła być próbą powrotu do tego materiału. Jednak po upływie blisko dekady Hitchcockowi doskwierały

33 D. Auiler, Hitchcock's Secret Notebooks..., s. 443.

34 C.T. Samuels, Encountering Directors, New York 1972, s. 249-250.

35 J. Orr, op. cit.

36 D. Spoto, op. cit., s. 543-544.

Prace Kulturoznawcze 22, 2018, nr 3

(C) for this edition by CNS 
już wiek i zdrowie, brakowało mu energii i stanowczości, aby wskrzesić projekt Kalejdoskopu w jego pierwotnej postaci. Szał okazał się filmem przestylizowanym i dość miałkim, zwłaszcza w porównaniu ze swoim rzekomym pierwowzorem.

Analizy wypowiedzi samego Hitchcocka, w szczególności wywiadu, który przeprowadził z nim J. Danvers Williams, a który został wydany pod wiele mówiącym tytułem Cenzorzy by tego nie przepuścili (The Censor's Wouldn't Pass $I t)^{37}$, a także esejów: Filmy, które moglibyśmy zrobić (Films We Could Make) ${ }^{38}$, Gdybym byt szefem wytwórni filmowej (If I Were Head of a Production Company) ${ }^{39}$ oraz Reżyserzy sa martwi (Directors Are Dead) ${ }^{40}$, wskazują, że był głęboko świadom problemów wynikających z amerykańskiego systemu produkcji filmowej. Hitchcock pisał, że istnieją dwie szkoły rozumienia roli reżysera w procesie produkcyjnym: brytyjska - dająca reżyserowi kredyt zaufania i pewną swobodę twórczą — i amerykańska, która traktuje reżysera jako wykonawcę woli wytwórni, stwarzającej mu wszelkie warunki do dobrego wykonania stawianego przed nim zadania. W konsekwencji — jak stwierdził Hitchcock — mimo że amerykańskie produkcje są eleganckie, sprawne i efektywne, często brakuje im tego, co należałoby nazwać „duszą" ${ }^{1}$. Z drugiej strony, nieporozumienia między producentem a reżyserem są z reguły jedną z głównych przyczyn klęski projektów filmowych — dlatego nie ma tutaj miejsca na kompromisy, na czele produkcji musi stać jedna osoba, jeden autorytet. Szczególnie ważna jest kwestia kontroli nad scenariuszem, która powinna spoczywać w rękach osoby mogącej najbardziej obiektywnie dostrzec oczekiwany potencjał. Problem tego swoistego dysonansu w procesie produkcji filmowej najtrafniej ujął, pisząc:

Drżę na myśl o tych filmach, które nie udały się przez wszechpotężnego reżysera, bez odpowiedniego polotu, któremu pozwolono robić, co zechce [...]. Drżę na myśl również o tych filmach, które nigdy nie spełniły pokładanych w nich nadziei, za sprawą staromodnego producenta, który nie dbał o nic poza pieniędzmi ${ }^{42}$.

Wspominając brytyjski okres swojej twórczości, Hitchcock mówił: „Ciągle sugerowałem producentom pomysły inspirowane autentycznymi wydarzeniami, by usłyszeć tylko - wybacz Hitch, ale cenzorzy tego nie przepuszczą. By wypowiedzieć na ekranie brutalność, która mnie interesuje, zostałem zmuszony do tworzenia fikcji" ${ }^{43}$. Przytoczone cytaty ukazują skomplikowaną sieć powiązań między Hitchcockiem-reżyserem i Hitchcockiem-artystą. Uwikłanie w zawiłości procesu produkcyjnego, zwłaszcza w warunkach amerykańskiego kina, doprowadziło projekt Kalejdoskopu do tego zabójczego dla filmów impasu pomiędzy

37 Hitchcock on Hitchcock..., s. 192-202.

38 Ibidem, s. 165-168.

39 Ibidem, s. 172-176.

40 Ibidem, s. 183-186.

41 Ibidem, s. 187.

42 Ibidem, s. 184.

43 Ibidem, s. 198.

Prace Kulturoznawcze 22, 2018, nr 3

(C) for this edition by CNS 
twórcą a finansującym go producentem. Ani jedna, ani druga strona nie była przy tym skłonna do kompromisów - wszakże i samo dzieło miało być bezkompromisowe. Czy jednak termin ,zbyt radykalny”, tak często stosowany w kontekście tego nieukończonego projektu, jest tu odpowiedni? Koniec końców, nie chodziło o radykalizm materiału, ale ortodoksję producentów — obawiających się o pieniądze - i nieprzejednanie twórcy, chcącego wreszcie wyrwać się z ograniczeń, które towarzyszyły mu w ciągu całej kariery. Wyłania się tu swoisty paradoks reżysera - twórcy, rozumianego jako „marka”, która była sukcesywnie budowana przez inwestycje wytwórni. W tamtych czasach producenci często traktowali reżyserów i gwiazdy jako swoje długoterminowe inwestycje.

Wróćmy zatem do pytania postawionego na początku: do której kategorii nieukończonych dzieł zaproponowanych przez Sidneya Gottlieba zaliczyć należy Kalejdoskop? Wydaje się, że projekt ten należał do dzieł nieukończonych od samego początku, których nowatorstwo i artystyczna wizja wykraczały tak daleko poza ograniczenia swojego czasu, że nie miał on szans na bycie zrozumianym. Ogromny entuzjazm i zaangażowanie Hitchcocka należy tłumaczyć jego chęcią wyjścia poza kanony, które sam sobie wyznaczył. Zainspirowany neorealizmem i nowymi falami europejskiego kina, chciał przenieść tę energię twórczą i nowatorstwo techniczne na amerykański grunt. Rozmowy z Truffautem, który ogromnie mu schlebiał i zabiegał o jego uwagę, przekonując go, że jego styl jest prawdziwą kwintesencją kina autorskiego, utwierdziły go w przekonaniu, iż może pozwolić sobie na swobodę właściwą twórcom kina niezależnego. Splot czynników, które przyczyniły się do śmierci Kalejdoskopu, pokazuje jednak, że film, w którym komercja i sztuka nieustannie się z sobą stykają, bywa niewdzięczną dla artysty dziedziną. Mimo że dziś nikt nie kwestionuje pozycji Hitchcocka jako wybitnego artysty i wizjonera kina, historia Kalejdoskopu pokazuje, iż nie był on w stanie uciec od komercyjnych więzów, jakie narzucił nań jego własny sukces. Można nawet przypuszczać, że wytwórnia oraz krytycy nie obawiali się radykalności i wizualnego realizmu projektu, ale nie chcieli, aby Hitchcock przestał być reżyserem komercyjnie opłacalnym. Szok, jaki niewątpliwie wywołałby film na miarę Kalejdoskopu, z pewnością pozostałby jednym z najważniejszych punktów kariery Hitchcocka. Ostrożność wytwórni jest zrozumiała, film jest wszakże inwestycją niezwykle kosztowną, a funkcją producenta jest również dyscyplinowanie reżyserów. $Z$ całą pewnością jednak, wbrew wysuwanym niekiedy zarzutom, projekt ten nie był jedynie ostatnim zrywem, łabędzim śpiewem wielkiego, ale starzejącego się reżysera, który chciał nadal liczyć się w grze. Hitchcock wierzył w swoją wizję i był przekonany, że może zmienić amerykańskie kino. Niestety, nigdy już nie dowiemy się, jaka byłaby reakcja widowni na śmiały Kalejdoskop, trudno jednak uwierzyć, że twórca tak dobrze rozumiejący i „czujący” widownię jak Hitchcock mógłby się zupełnie pomylić. Późniejsza historia kina, a zwłaszcza prawdziwy renesans horroru $\mathrm{w}$ drugiej połowie lat siedemdziesiątych pokazują wszak, że widzowie nieustannie spragnieni są silniejszych wrażeń. 


\section{Too radical to be completed? \\ The case of Kaleidoscope, the last, unfinished film of Alfred Hitchcock}

Abstract

Between 1964 and 1967, at the end of his illustrious career, Alfred Hitchcock experienced an extraordinary moment of creative renaissance. Inspired by the dynamism and innovativeness of European cinema, he decided to reach for the subject and creative means that were ahead of his time. Unfortunately, one of the potential masterpieces of contemporary cinema has been hailed too radical, shocking and even repulsive to be made. This article is an attempt to reconstruct the intricate fate of the Kaleidoscope, the last of the unfinished film projects of Alfred Hitchcock. The existing materials and available sources have been analyzed and systematized in order to find an answer to a number of research questions, and in the end to try to find an answer to the most important one: why a project so meticulously prepared, and in many ways visionary has become an "unfinished work"? Moreover, within the scope of attainable facts an attempt has been made to reconstruct the motivations and the main stylistic and narrative motifs of the film. The potential relations between this project and the director's earlier works, Psycho (1960) as well as later Frenzy (1972), have also been examined.

Keywords: Alfred Hitchcock, unfinished work, Kaleidoscope, Frenzy

\section{Bibliografia}

Ackroyd P., Alfred Hitchcock, New York 2015.

Adair G., Alfred Hitchcock: Filming Our Fears, Oxford 2002.

Auiler D., Hitchcock Lost: The Lost Silent and Frenzy 67, Los Gatos 2013.

Auiler D., Hitchcock's Secret Notebooks, New York 2001.

Fromm E., Anatomia ludzkiej destrukcyjności, przeł. J. Karłowski, Poznań 1998.

Gottlieb S., Hitchcock on Hitchcock, Berkeley 1997.

Gottlieb S., Unknown Hitchcock: The Unrealized Projects, [w:] Hitchcock: Past and Future, red.

R. Allen, S. Ishii-Gonzales, London 2004.

Haynes J.E., Truffaut-Hitchcock, [w:] A Companion to François Truffaut, red. A. Dudley, A. Gillain, Hoboken 2013.

Hitchcock A., Films We Could Make, [w:] Hitchcock on Hitchcock, red. S. Gottlieb, Berkeley 1995. Levin J., Fox J.A., Normalcy in Behavioral Characteristics of the Sadistic Serial Killer, [w:] Serial

Murder and the Psychology of Violent Crimes, red. R.N. Kocsis, New York 2008.

McGilligan P., Alfred Hitchcock: A Life in Darkness and Light, New York 2003.

Orr J., Hitchcock and Twentieth-century Cinema, New York 2005.

Perry G., The Films of Alfred Hitchcock, Worthing 1965.

Russell Taylor J., Hitch: The Life and Times of Alfred Hitchcock, Cambridge, MA 1978.

Samuels C.T., Encountering Directors, New York 1972.

Spoto D., The Dark Side of Genius: The Life of Alfred Hitchcock, Cambridge, MA 1999.

Walker M., Hitchcock's Motifs, Amsterdam 2005. 
White P., Hitchcock and Hom(m)osexuality, [w:] Hitchcock: Past and Future, red. R. Allen, S. Ishii-Gonzales, London 2004.

Witty S., The Alfred Hitchcock Encyclopedia, Lanham 2016.

\section{Źródła internetowe}

http://mysterymanonfilm.blogspot.com/2009/02/murder-scene-written-by-hitchcock.html (dostęp:

3 listopada 2018).

http://www.bbc.com/culture/story/20180620-why-hitchcocks-kaleidoscope-was-too-shocking-tobe-made (dostęp: 3 listopada 2018).

http://www.writingwithhitchcock.com/frenzy.html (dostęp: 5 listopada 2018). 